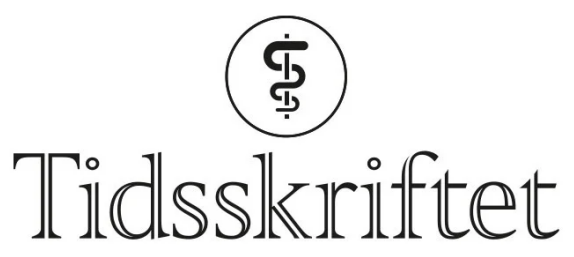

DEN NORSKE LEGEFORENING

\title{
Malariamyggens sirkulasjonssystem kartlegges
}

VERDENS HELSE

KRISTOFFER BRODWALL

Email: kristoffer.brodwall@gmail.com

Barneklinikken

Haukeland universitetssykehus

Fotografier tatt gjennom mikroskop av Anopheles, myggen som overfører malaria, gir innsikt i insektets sirkulasjon.

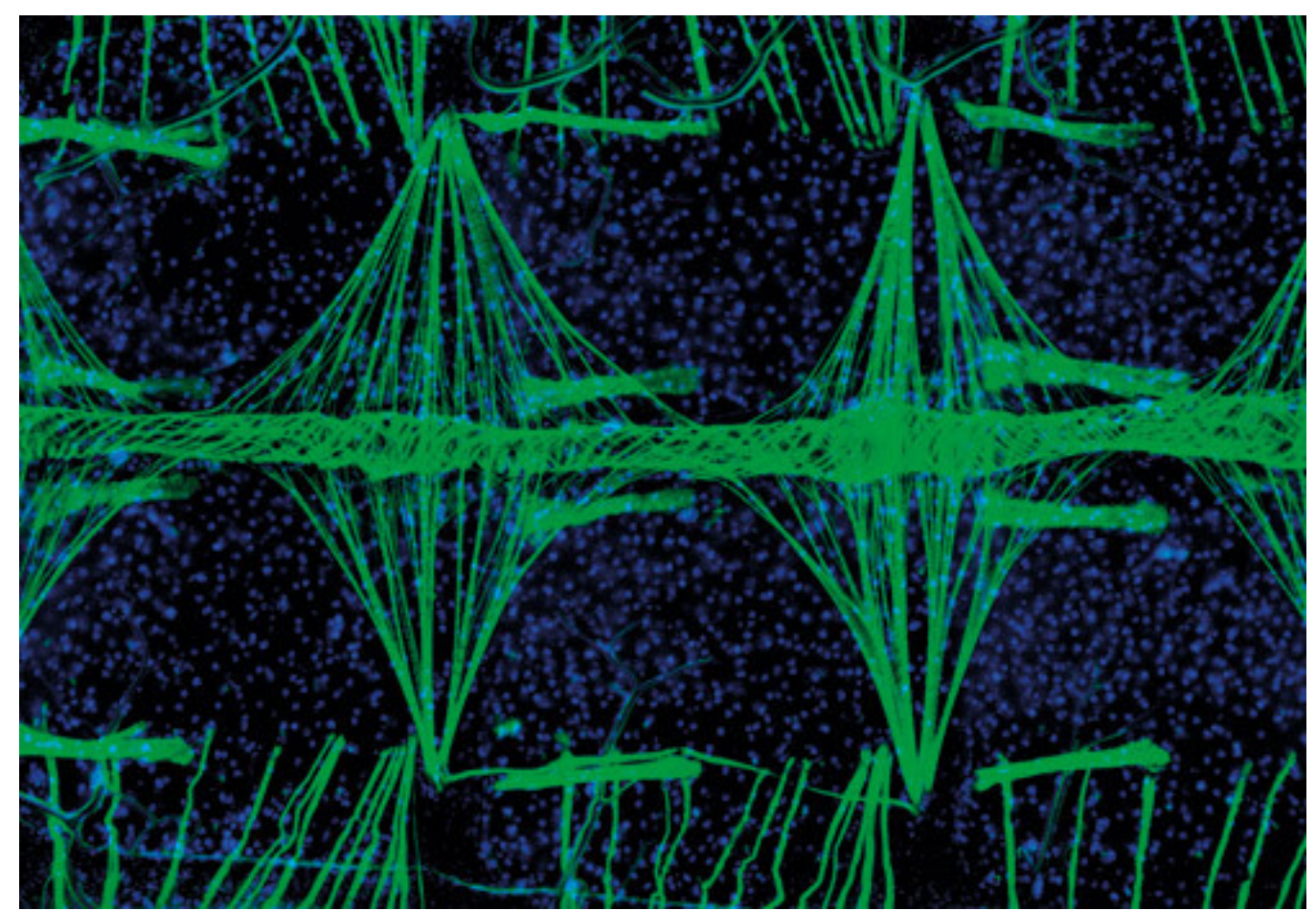

Anopheles gambiae - myggens sirkulasjonssystem. Foto Jonas King, Hillyer Lab, Vanderbilt University

Bildet over er blitt mye omtalt etter at det ble kåret til vinner av 2010 Nikon Small World Photomicrography Competition. Her fremstilles det sirkulatoriske systemet til Anopheles gambiae forstørret ved hjelp av fluorescensteknologi (1). Det er tatt av Jonas King. Flere 
bilder finnes i en artikkel som omhandler kartlegging av myggens sirkulatoriske system (2) $)$.Vi ser et rørformet hjerte hengt opp i seks par vingemuskler (alary muscles), som deler hjertet i seks segmenter og bidrar til pumpeevnen.

Som andre insekter har Anopheles-myggen et åpent sirkulasjonssystem med en karstreng langs ryggen samt en kroppshule (hemocoel). Den dorsale karstrengen deles i et abdominalt hjerte og en torakal aorta. Hjertets muskler er organisert sirkulært i et heliksmønster og pumper hemolymfen (blod/kroppsvæske) med en hastighet på $8 \mathrm{~mm} / \mathrm{s}$. Hemolymfen kan gå i begge retninger, avhengig av hvor den peristaltiske bølgen starter, og kommer tilbake fra hemocoel gjennom klaffer på sidene av karstrengen. Det finnes også aksessoriske pumpeorganer perifert i insektene (므).

Malaria smitter ved at Anopheles-myggen spiser et blodmåltid som inneholder plasmodier. Kunnskap om insektets struktur er medisinsk interessant - fordi det kan bidra til å kartlegge hvordan malariaparasittene transporteres gjennom myggen og dermed gi grunnlag for nye metoder for å begrense overføring av sykdommen.

\section{LITTERATUR}

1. Nikon. Mosquito Heart Captures First Place in 2010 Nikon Small World Competition www.nikoninstruments.eu/en_DK/News/European-News/Mosquito-Heart-Captures-First-Place-in2010-Nikon-Small-World-Competition (9.11.2010).

2. Glenn JD, King JG, Hillyer JF. Structural mechanics of the mosquito heart and its function in bidirectional hemolymph transport. J Exp Biol 2010; 213: 541-50.

Publisert: 16. desember 2010. Tidsskr Nor Legeforen. DOI: 10.4045/tidsskr.10.1244

(C) Tidsskrift for Den norske legeforening 2023. Lastet ned fra tidsskriftet.no 26. april 2023. 